\title{
Plant Community Establishment in a Coastal Marsh Restored Using Sediment Additions
}

\author{
Rebecca J. Howard ${ }^{1}$ (1) P Patricia S. Rafferty ${ }^{1,2} \cdot$ Darren J. Johnson $^{3}$ \\ Received: 12 June 2019 / Accepted: 22 August 2019/ Published online: 23 October 2019 \\ (C) The Author(s) 2019
}

\begin{abstract}
A goal of wetland restoration is the establishment of resilient plant communities that persist under a variety of environmental conditions. We investigated the role of intraspecific and interspecific variation on plant community establishment in a brackish marsh that had been restored by sediment addition. Plant growth, sediment accretion, and surface elevation change in planted, not-planted, and nearby reference sites (treatments) were compared. Four perennial macrophytes were planted: Bolboschoenus robustus, Distichlis spicata, Phragmites australis, and Schoenoplectus californicus. There was $100 \%$ survival of the planted species, and all exhibited rapid vegetative spread. Intraspecific variation in stem height and cover was identified, and interspecific comparisons also indicated differences in species cover. Treatment comparisons revealed that final total cover at not-planted sites was equivalent to that at reference sites, and was highest at planted sites where $P$. australis became dominant. Species richness was initially highest at the reference sites, but final richness was equivalent among treatments. Soil surface elevation was greater at planted compared to not-planted and reference sites. Because of the rapid cover and increased surface elevation generated by planted species, the resiliency of restored coastal marshes may be enhanced by plantings in areas where natural colonization is slow and subsidence is high.
\end{abstract}

Keywords Brackish marsh · Colonization · Intraspecific and interspecific growth differences · Marsh restoration · Plant community composition $\cdot$ Sediment addition

\section{Introduction}

Effective wetland restoration requires that hydrologic regimes and soils support the growth and persistence of wetlandadapted plant communities. While hydrology and soils are recognized as major influences on wetland structure and function, other factors that affect the outcome of wetland restoration efforts include disturbance regimes, topography, nutrient

Electronic supplementary material The online version of this article (https://doi.org/10.1007/s13157-019-01217-z) contains supplementary material, which is available to authorized users.

Rebecca J. Howard

howardr@usgs.gov

1 U.S. Geological Survey, Wetland and Aquatic Research Center, Lafayette, LA 70506, USA

2 Present address: National Park Service, Gateway National Recreation Area, Staten Island, NY 10305, USA

3 Cherokee Nation Technology, Wetland and Aquatic Research Center, Lafayette, LA 70506, USA availability, and seed and propagule supply (Zedler 2000). Deposition of sediments dredged from open water or riverine habitats is a primary method used to create or restore wetlands. Dredging sediments within wetlands became common in the USA in the 1930's, when both bucket and low-pressure hydraulic dredges were used to excavate canals for oil and gas exploration in coastal Louisiana (Cahoon and Cowan 1988). The sediments were stacked along the canal sides, contributing to high wetland loss through altered hydrologic patterns and increased saltwater intrusion (Bass and Turner 1997). The first projects using dredged sediments to create or restore marshes were based in North Carolina in the 1960s (Craft 2016, p 289). Marsh restoration using sediment addition consists of distributing sediments within degraded marshes (i.e., marshes characterized by high plant mortality); these projects have the goal of increasing soil surface elevation to a level that supports vegetation growth (Turner and Streever 2002).

The results of adding sediments, or sediment subsidy, in marsh restoration have been studied extensively (Elsey-Quirk et al. 2019). Sediment slurries, defined as sediments with a high fluid content of about $85 \%$ liquids and $15 \%$ solids 
(Mendelssohn and Kuhn 2003), are often used. Wetlands that have been restored using sediment addition include degraded salt marshes (Slocum et al. 2005; Croft et al. 2006; VanZomeren et al. 2018), marshes affected by large-scale vegetation dieback following drought (Schrift et al. 2008; Stagg and Mendelssohn 2010), tidal wetlands impacted by urban development (Haltiner et al. 1997), and deteriorating brackish marshes (La Peyre et al. 2009). The influence of surface elevation on soil physical and chemical properties (e.g., bulk density, reductionoxidation potential, nutrient concentration) in sediment-restored marshes has been noted (Croft et al. 2006; Stagg and Mendelssohn 2011; Kongchum et al. 2017; VanZomeren et al. 2018). Soil characteristics in turn influence the establishment and growth of restored marsh plant communities.

Transplanting rooted seedlings and seeding have been used to accelerate plant establishment in sediment-restored marshes. Early studies focused on use of Spartina alterniflora and Spartina patens in salt and brackish habitats, respectively (Seneca et al. 1976; Barko et al. 1977). Detailed information on seeding techniques, plant propagation, and plant spacing intervals have been developed for a variety of species (e.g., Thunhorst 1993). Planting at 1-m intervals was estimated to require $50 \mathrm{~h}$ of labor per ha (Broome et al. 1988), at a cost of up to $\$ 8500$ per ha (Utomo et al. 2010). Natural plant colonization and succession in restored or created wetlands have also been studied. For example, S. alterniflora colonized and became dominant at a created salt marsh in Louisiana, where it was also dominant in natural marshes (Edwards and Proffitt 2003). However, other created marshes at the site, which had comparatively higher elevation, were colonized by the high marsh species Spartina patens and Distichlis spicata and shrubs (Edwards and Proffitt 2003). Following sediment addition in a degraded Louisiana salt marsh, Schrift et al. (2008) found that plant cover at low elevation sites was equivalent to that of healthy reference marshes at the end of the second growing season, while cover was lower at higher-elevation restored sites. In general, research has indicated that, if soil surface elevations are appropriate, natural colonization by wetland plants will occur following sediment addition, but the time frame and pace will vary depending on the availability of seeds and propagules and site characteristics.

Alterations in environmental factors in coastal areas resulting from climate change, including increased salinity and depth of tidal flooding associated with rising sea levels, sediment erosion, and altered precipitation and temperature regimes, can act as stressors affecting the establishment and persistence of plant communities. Variation in stress tolerance can exist within and between plant species, affecting overall community structure and function. Genetic diversity in clonal wetland species has been documented (e.g., Silander 1984; Brix 1999; Seliskar and Gallagher 2000; Ivey and Richards 2001; Travis et al. 2002; Richards et al. 2004; Sweetman et al. 2013; Hughes and Lotterhos 2014; Kettenring 2016). As a reflection of this diversity, intraspecific variation in response to environmental stressors exists (e.g., Lessmann et al. 1997; Hester et al. 1998; Smith and Proffitt 1999; Howard and Rafferty 2006; Howard 2010). Genetic variation among keystone marsh species has been noted to affect ecosystem properties (Seliskar et al. 2002). Zerebecki et al. (2017) found that intraspecific variation in the salt marsh foundation species Spartina alterniflora affected plant-plant and plant-herbivore interactions, and Tumas et al. (2018) noted the importance of genotypic diversity in preserving the adaptive potential of species following wetland restoration. Additional consequences of high genetic diversity in wetlands include the promotion of species coexistence (Vellend 2006), resiliency to disturbance (Brewer and Bertness 1996; Hughes and Stachowicz 2011), increased productivity and nutrient retention (Zedler 2005; Reynolds et al. 2012), increased seed production (Sweetman et al. 2013), and altered species interactions (Proffitt et al. 2005). Field studies that examined the performance of different genotypes within species following restoration used transplanted S. alterniflora (Proffitt et al. 2003; Hughes 2014) and Zostera marina, (Hughes and Stachowicz 2011), and seeds of Z. marina (Reynolds et al. 2012). To our knowledge, however, there are no published studies that examined the effect of multiple individuals within a suite of species on plant community composition and structure at wetland restoration sites.

We investigated the influence of intra- and interspecific variation on plant community establishment and structure in a brackish marsh that was restored using sediment addition. The overall goal was to provide a base for the development of a vigorous plant community capable of sustaining marsh elevation, thereby preventing further marsh degradation and conversion to open water habitats. Plant community establishment, species composition, soil accretion and soil surface elevation change were documented. Marsh treatments included sediment-addition sites with vegetation plantings, sedimentaddition sites without plantings, and nearby reference sites that were not affected by sediment addition. Our study addressed the following questions: (1) does intraspecific variation within planted species result in growth differences among individuals of the species? (2) does interspecific variation affect plant community composition and structure on planted sediment addition sites? (3) do species cover and composition vary among marsh treatments? and (4) do soil properties, accretion rates, and surface elevation change vary among treatments?

\section{Materials and Methods}

\section{Study Area}

The study was conducted in a brackish marsh along Bayou Dupont in the Barataria Basin of southeast Louisiana, USA (Fig. 1). The nearest tide station, located about $35 \mathrm{~km}$ south at 


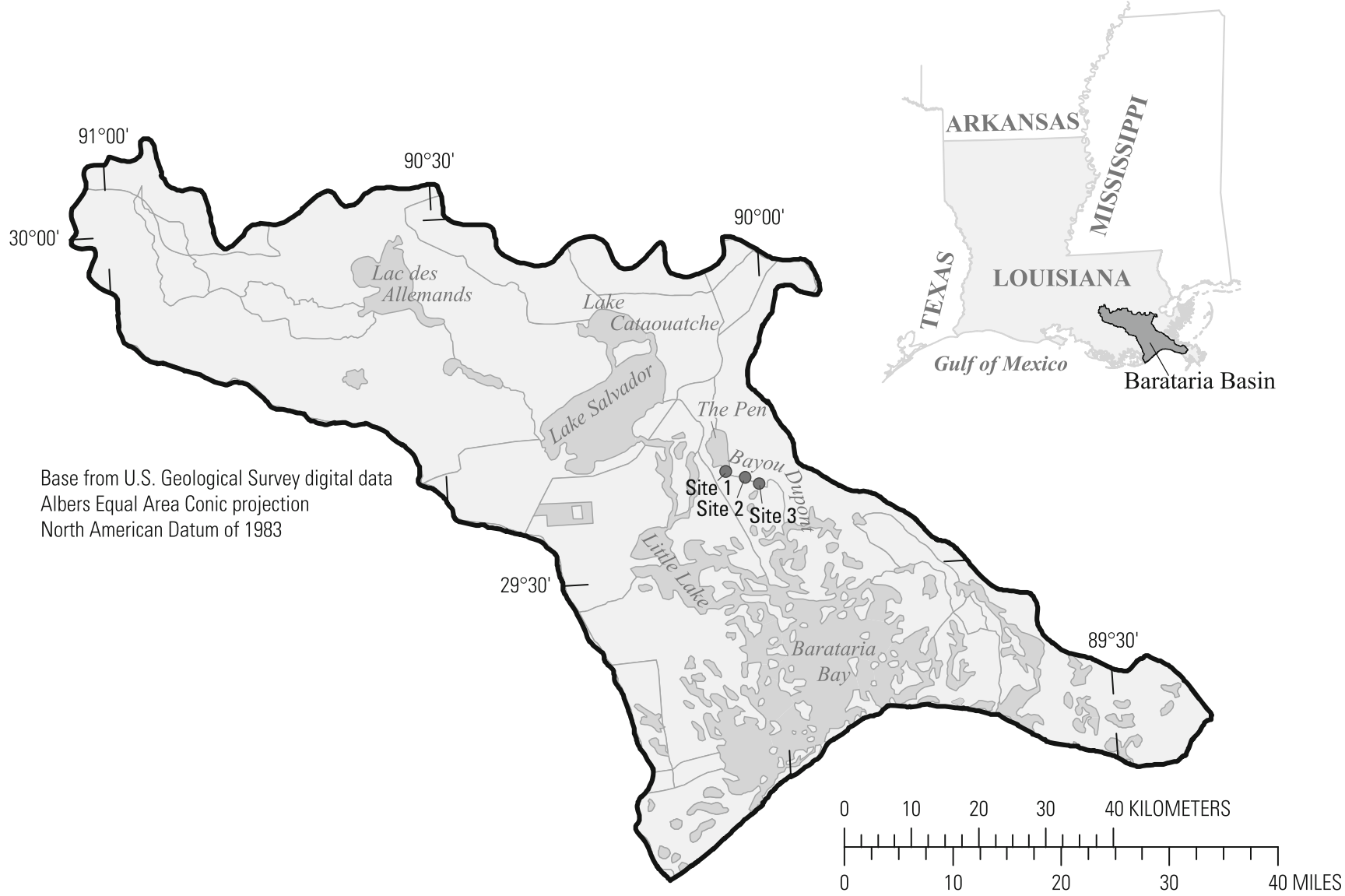

Fig. 1 Location of three study sites in the Barataria Basin of southeast Louisiana. Site 1 and site 2 were spaced about 3 km apart along Bayou Dupont

Grand Isle, Louisiana, experiences a diurnal micro-tidal range of $0.32 \mathrm{~m}$ and a relative sea-level rise rate of $9.08 \pm$ $0.42 \mathrm{~mm} \mathrm{yr}^{-1}$ (NOAA 2019). Prior to restoration the marsh was in a degraded state, as evidenced by numerous shallow $(<$ $0.75 \mathrm{~m}$ deep) interior open-water areas. The dominant emergent plant species was Spartina patens; other commonlyoccurring species included Distichlis spicata, Lythrum lineare, Ipomoea sagittata, Kosteletzkya pentacarpos, Solidago sempervirens, and Seutera angustifolia. The restoration goal was to raise soil surface elevation to a level capable of supporting the growth of emergent vegetation. A small, mobile, low-pressure hydraulic dredge (pipe diameter of $30.5 \mathrm{~cm}$ ) was used in the summer of 2000 to pump sediment from the adjacent bayou into open water areas of the marsh; sediment was added to an elevation about $15 \mathrm{~cm}$ above the remaining marsh surface to compensate for dewatering and compaction. An area of about 65 ha received sediment during the dredge operation.

\section{Plant Material}

The following commonly-occurring macrophytes native to coastal Louisiana marshes were included in the study: Bolboschoenus robustus (sturdy bulrush), D. spicata (saltgrass), Phragmites australis (common reed), and Schoenoplectus californicus (California bulrush). All are perennial, clonal species that regenerate through both vegetative propagation and sexually through seed production. They occur across a range of salinities in Louisiana marshes; B. robustus and D. spicata are found primarily in brackish (5-20 psu) to salt (20-30 psu) marshes while P. australis and $S$. californicus occur primarily in fresh to intermediate marshes (0.5-5 psu); however, P. australis has been found in brackish marshes up to 20 psu (Penfound and Hathaway 1938; Chabreck 1972). To obtain a variety of genetic individuals, five to ten individual plants of each species were collected across the approximately $340 \mathrm{~km}$-long Louisiana coastline along the Gulf of Mexico. Several culms connected by a single rhizome were retained to represent a single individual plant, and just one individual per species was collected at a location. Genetic analyses were not conducted; we assumed that genetic variation was present due to the distance between collection locations. The plants were transported to a greenhouse facility in Lafayette, Louisiana, where they were separated into ramets and vegetatively propagated through several generations under common garden conditions (freshwater, flooded to sediment surface). The original plants collected were assigned identification numbers; the propagated ramets 
retained that identification number (individual number) and were used in a series of experiments. Additional details on field collection procedures are provided in Howard and Rafferty (2006). For this study, experimental plants were conditioned to 13 psu salinity before transport to the field site.

\section{Experimental Design}

Three locations along Bayou Dupont were selected in May 2001, approximately 9 months after sediment addition. Four sites were established at each location; two sites were randomly assigned as planted treatments (hereafter $\mathrm{P}$ ) and two as not-planted treatments (hereafter NP). All sites on the sediment deposits were void of vegetation at the experiment's initiation. A healthy-appearing marsh site that was not affected by sediment addition and supported high vegetation cover was selected near each location as a reference treatment (hereafter R). The study therefore included six replicates of the $\mathrm{P}$ and NP and three replicates of R, for a total of 15 sites.

Each site (P, NP, and R treatments) was protected by an exclosure to prevent herbivory by the introduced rodent Myocastor coypus (nutria), a species that causes extensive vegetation damage in Louisiana wetlands (Taylor and Grace 1995; Evers et al. 1998; Ford and Grace 1998). The exclosures were constructed of vinyl-coated wire about $1.5 \mathrm{~m}$ in height that was sunk $30 \mathrm{~cm}$ into the substrate to prevent $M$. coypus from burrowing beneath. The dimensions of the exclosures (hereafter called units) were $9.5 \mathrm{~m} \times 7.75 \mathrm{~m}$. Because of the unconsolidated substrate, boardwalks were placed within each unit to prevent damage during data collection. The boardwalks divided the unit length into four columns, and seven rows in each column were designated; this provided a grid system with 28 cells (see Howard et al. 2008 for details). In the planted treatment each species was randomly assigned to one of the four columns, and within each column different individual plants within the species were randomly assigned to rows 1-6; row 7 was reserved for destructive sampling of soil accretion and elevation (see below). A $1-\mathrm{m}^{2}$ area at the center of each cell was identified, and two ramets of an individual plant of the assigned species were planted $30-\mathrm{cm}$ apart. Six different individuals of $B$. robustus, $P$. australis, and $S$. californicus were planted; the planting of an individual of Paspalum sp. mistakenly identified at collection as D. spicata resulted in just five individuals of this species in the experiment.

Rod surface elevation tables (RSETs) were installed at all treatments to measure relative soil surface elevation, or vertical land motion (VLMw) of the wetland surface over time (Cahoon et al. 2002; Cahoon 2015). The RSET device consists of a series of connected steel rods driven into the sediment to refusal, serving as a benchmark; see Cahoon (2015) for details on measurement techniques. Marker horizons $(\mathrm{MH})$, consisting of a clay (feldspar) layer spread on the soil surface, were placed near each RSET to allow measurement of sediment accretion (Cahoon and Turner 1989). The RSETMH stations were placed in row 7 cells in one of the two planted units at each location. Each designated cell 7 was planted as described above with two ramets of a randomlyselected individual of the species assigned to that column. This resulted in 12 RSET-MH installations in the planted treatment (four installation at each of three locations). A single RSET-MH station was installed in a randomly-determined row-7 cell of one of the not-planted treatments at each location, as well as at each reference treatment. These six additional installations resulted in a total of 18 RSET-MH stations.

\section{Data Collection}

Plant Growth Data were collected within a $1-\mathrm{m}^{2}$ quadrat positioned at the cell centers at approximately monthly intervals through two growing seasons (May 2001 to November 2002) and in April 2003, for a total of 19 measurement times. All cells were sampled in $\mathrm{P}(n=28)$; in NP and R, two cells in each column were randomly selected as permanent sampling locations $(n=8)$. Cover class by species, total cover, planted species maximum height, and planted species distance of lateral spread were measured. The cover class of bare substrate was also recorded. Cover class was estimated using a modified Braun-Blanquet system as follows: (P) $<1 \%$, (1) $1-10 \%$, (2) $11-25 \%$, (3) $26-50 \%$, (4) $51-75 \%$, and (5) $76-100 \%$. Because vegetation often occurred in layers, it was possible for total cover in a quadrat to exceed $100 \%$. The number of stems and stem height of all species were measured within a $15 \mathrm{~cm} \times 15 \mathrm{~cm}\left(0.0225 \mathrm{~m}^{2}\right)$ sub-quadrat located at the center of the $1-\mathrm{m}^{2}$ quadrat in September 2001 and 2002 and in April 2002 and 2003; only live stems with at least $50 \%$ green tissue were included. At the conclusion of the experiment a soil core $(10.2 \mathrm{~cm}$ diameter $\times 35 \mathrm{~cm}$ deep) was collected from one randomly-selected cell in each column of the 15 units. The cores were placed on ice until transported to the laboratory, washed to remove soil, and dried at $80^{\circ} \mathrm{C}$ to a constant mass for determination of total belowground biomass.

Salinity and Soil Characteristics Surface and soil interstitial water salinity were measured during each site visit. Interstitial water was collected at $15 \mathrm{~cm}$ depth at two to three randomly selected locations within each unit using a syringe attached to thin, rigid plastic tubing inserted into the soil. A soil core $(10.2 \mathrm{~cm}$ diameter $\times 30 \mathrm{~cm}$ deep $)$ was collected outside of and adjacent to each of the 15 units in July 2001 and March 2003. The cores were divided into depth categories $(0-10 \mathrm{~cm}, 10-20 \mathrm{~cm}$, and $20-30 \mathrm{~cm})$ and stored on ice for transportation to the laboratory. Wet weight of each core section was determined, and samples were placed in a forced-air oven at $80^{\circ} \mathrm{C}$ and dried to a constant mass for determination of bulk density. The dried soil was ground in a commercial 
mill, and subsamples were used for determination of percent organic matter using the loss on ignition method (modified from Ben-Dor and Banin 1989) and percent sand, silt, and clay (Sheldrick and Wang 1993).

Soil Surface Elevation and Sedimentation The sites were allowed to recover from installation disturbance for four weeks prior to baseline RSET measurements, which were obtained in June 2001. Four compass positions were selected for VLMw measurement, and at each position nine elevation measurements were obtained (see Cahoon 2015 for details). At the time of initial VLMw measurements two marker horizons were placed in each cell in the vicinity of the RSET benchmark. Soil accretion was first measured during the subsequent VLMw measurement, in October 2001. A hollow copper rod was inserted into the soil surface and liquid nitrogen gas was pumped into the rod, creating a layer of frozen soil attached to the rod. The depth of soil above the marker horizon was measured to the nearest millimeter. Elevation and accretion measurements were obtained using these techniques at approximately three month intervals over two years, with final measurements in April 2003; a total of seven postbaseline data collections were made.

\section{Statistical Analyses}

Plant Growth All cover class variables were converted to midpoint values for analyses. Intraspecific variation was examined for the first growing season only; because the plants grew rapidly, individual plants could not be visually distinguished after that time (i.e., individuals of a species grew into adjoining cells). To investigate intraspecific variation, species were analyzed separately using repeated measures analysis of variance (ANOVA) with individual plant identification as the independent variable. Cover of individual plants and their maximum height were dependent variables using the first four measurement times (May to September). Maximum lateral spread as a response was examined using data collected two times in the first growing season, in August and September, also using repeated measures ANOVA. Data quantifying individual plant stem number and stem mean height were examined for September of the first growing season using ANOVA.

Individuals within a species were pooled for analyses of interspecific variation. To ensure sufficient degrees of freedom to conduct analyses of cover variables, a subset of six of the 19 total measurement times was used. The subset consisted of early, mid, and late growing-season dates throughout the study (July and September 2001; April, July, and September 2002; and April 2003). The first date was about eight weeks following planting. Dependent variables in the repeated measures ANOVA were planted species percent cover and relative percent cover (i.e., the percent of total cover in a quadrat that was the planted species), and planted species maximum height.
Maximum lateral spread of the planted species was analyzed using four measurement times in the first growing season, from early August to late October. All four measurement times for stem characteristics were used in repeated measures ANOVA with planted species stem number and mean height as dependent variables.

To examine treatment differences (i.e., P, NP, R), the $1-\mathrm{m}^{2}$ quadrats within the units were designated as subsamples; cells containing RSET-MH stations were not included in these analyses because of destructive sampling within them. Subsample number was therefore 24 in P and eight in NP and R. The six measurements times described above were included in the repeated ANOVA analyses for treatment comparisons. Response variables examined were total cover and species richness, and percent cover of $P$. australis, Spartina alterniflora, Spartina patens, and bare ground. Stem number and mean height were also examined over the four measurement times by using repeated measures ANOVA. Similarity of vegetation between treatments was examined by using the Sørensen coefficient (equivalent to the Steinhaus coefficient), as described in Kent (2012). Both presence/absence and cover data (mean by species per treatment) were used. Analyses were conducted using two collection dates: the peak of the second growing season after planting (August 2002) and early in the third growing season (April 2003). We also investigated similarity between treatments at these two dates using analysis of similarity (ANOSIM) and multiresponse permutation procedures (MRPP). Treatment differences in belowground biomass were analyzed by using one-way ANOVA with the four samples within a unit treated as subsamples.

Salinity and Soil Characteristics Surface and interstitial salinity treatment comparisons were made using two-way ANOVA with treatment and time as independent variables. Marsh treatment comparisons of bulk density, percent organic matter, and sand, silt and clay content were conducted separately by soil depth class and time using ANOVA. In addition, two-way ANOVA with treatment and time as independent variables was used to examine percent sand, silt, and clay responses with soil depths pooled.

Soil Surface Elevation and Sedimentation Invalid VLMw measurements (e.g., pin touched unmovable debris) were discarded. The mean of pin measurements for each compass position was determined, and elevation for the RSET station was defined as the mean of the four compass positions. Sediment accretion in the vicinity of each RSET was calculated as the mean of the two marker horizons. The four RSET$\mathrm{MH}$ stations in planted treatments were included as subsamples in these analyses. Data were first examined within each treatment to determine if significant change occurred over time (i.e., if conditions varied from baseline). VLMw data were expressed as cumulative change from baseline 
conditions and were examined using linear regression analysis. Accretion data were analyzed in the same manner as VLMw data. Linear rates of change among treatments were compared using regression analysis.

All repeated measures ANOVA (PROC MIXED), ANOVA (PROC GLM), and regression analysis (PROC REG), were conducted using SAS software (ver. 9.3; SAS Institute, Inc., Cary, North Carolina). Response variables that did not meet required assumptions for normality and homogeneity were transformed. The significance level for analyses was $\alpha \leq$ 0.05 ; for multiple comparisons the significance level was adjusted using the Bonferroni correction. ANOSIM and MRPP analyses were conducted using $\mathrm{R}$ software, vegan package (Oksanen et al. 2019).

\section{Results}

\section{Plant Growth}

Intraspecific Variation All individuals of the four species survived the first growing season following planting. There were no differences among $B$. robustus individuals and few differences among individuals of the other species (Table 1). One D. spicata individual (plant 5) had higher cover (59.46 \pm $5.13 \%$; mean $+\mathrm{SE}$ ) throughout the season compared to one other (plant 6; $46.60 \pm 4.62 \%$ ) regardless of measurement time; cover of this individual, however, was equivalent to that of the remaining three. The time/plant interaction found for D. spicata maximum height was expressed by greater height in plant 5 compared to two other individuals in July and three others in August. The time/plant interactions for $P$. australis and $S$. californicus maximum height were expressed as increasing values for some individuals throughout the summer, while in others the values did not differ between July and August. The maximum distance of lateral spread increased over time for all species, but there were no differences among individual plants within a species (Table 1). Analysis of stem number and mean stem height data collected in September of the first growing season also revealed no significant differences between individuals in any of the species (results not shown).

Interspecific Variation Species differences in growth responses were identified for all variables examined (Table 2). In the first growing season lateral spread of $B$. robustus and $P$. australis exceeded that of $S$. californicus and D. spicata (Fig. 2), while spread of $S$. californicus was less than that of all other species. The species with highest percent cover varied over time. For example, in July of the first growing season S. californicus cover $(21.44 \pm 4.72 \%)$ was equivalent to D. spicata $(47.17 \pm 3.27 \%)$, and lower than that of B. robustus $(57.03 \pm 6.91 \%)$ and $P$. australis $(58.14 \pm$
$5.42 \%)$. In July of the second growing season, however, $P$. australis cover $(88.00 \pm 0 \%)$ exceeded that of the other species (B. robustus, $3.69 \pm 2.00 \%$; D. spicata, $20.92 \pm$ $4.88 \%$; S. californicus, $21.44 \pm 4.72 \%$ ), and this relationship persisted throughout the remainder of the study. The decrease in abundance for species other than P. australis was also illustrated by the significant species/time interaction for relative percent cover (Fig. 3a). Maximum stem height of $P$. australis and S. californicus were similar early in the experiment, but height of the former species exceeded all other species by the end of the first growing season (Fig. 3b). There was a significantly higher number of stems of D. spicata $(21.80 \pm 3.02)$ compared to the other species at the first measurement time (B. robustus, $3.25 \pm 0.31$; P. australis, $2.42 \pm 0.48 ; S$. californicus, $1.31 \pm 0.53)$. At the conclusion of the experiment, however, D. spicata was absent from the sampling unit, and stem numbers among the other species were equivalent (B. robustus, $0.63 \pm 0.22 ;$ P. australis, $1.63 \pm 0.33 ; S$. californicus, $1.37 \pm 0.33)$. Initial mean stem height did not vary among the species (B. robustus, $77.90 \pm$ $4.72 \mathrm{~cm}$; D. spicata, $55.73 \pm 1.66 \mathrm{~cm}$; P. australis, $94.94 \pm$ $10.43 \mathrm{~cm}$; S. californicus, $47.49 \pm 15.60 \mathrm{~cm})$. During the remainder of the study P. australis mean height exceeded that of the other species. Final mean heights in April 2003 were: B. robustus, $63.73 \pm 13.50 \mathrm{~cm}$; P. australis, $165.11 \pm$ $21.61 \mathrm{~cm}$; and $S$. californicus, $89.42 \pm 22.34 \mathrm{~cm}(D$. spicata was absent from sample plots).

Treatment Comparison We identified 33 plant species that occurred within the quadrats over the 23-month study (Table S1). Colonization at NP was slow during the first growing season, as indicated by low total cover values (Fig. 4a). By spring of the second growing season, however, there was rapid establishment of plants at NP, and total cover increased rapidly. Total cover by the conclusion of the study was significantly greater at $\mathrm{P}(110.38 \pm 1.82 \%)$ compared to both $\mathrm{R}(64.92 \pm$ $4.10 \%)$ and NP $(56.40 \pm 4.03 \%)$; cover at the latter two was equivalent (Fig. 4a). Species richness at NP also remained low during the first growing season and, along with richness at $\mathrm{P}$, was significantly lower than richness at $\mathrm{R}$ early in the study (Fig. 4b). However, final richness was equivalent among the treatments $(\mathrm{NP}=2.48 \pm 0.33 ; P=3.12 \pm 0.39 ; \mathrm{R}=4.08 \pm$ $0.48)$.

Common plant species varied with treatment. While an equal number of ramets of three of the species (B. robustus, $S$. californicus, $P$. australis; two fewer ramets of $D$. spicata were planted) established in $\mathrm{P}, P$. australis became dominant by the beginning of the second growing season (Fig. 5). Aboveground runners of $P$. australis originating in $\mathrm{P}$ allowed this species to establish in some of the NP units; P. australis did not occur in R. Spartina alterniflora was dominant at NP, where its cover at the end of the second growing season was approximately $60 \%$. Cover of S. alterniflora was low in R and 
Table 1 Significance values from a repeated measures analysis of variance of intraspecific growth variation in four wetland macrophytes: Bolboschoenus robustus, Distichlis spicata, Phragmites australis, and Schoenoplectus californicus

\begin{tabular}{|c|c|c|c|c|}
\hline \multirow[b]{2}{*}{ Species } & \multirow[b]{2}{*}{ Model Effect } & \multicolumn{3}{|l|}{ Response } \\
\hline & & Cover $(\%)$ & Maximum Height (cm) & Lateral Spread $(\mathrm{cm})$ \\
\hline \multirow[t]{3}{*}{ B. robustus } & Plant & 0.9380 & 0.7348 & 0.5579 \\
\hline & Time & $<0.0001$ & $<0.0001$ & $<0.0001$ \\
\hline & Time*Plant & 0.9536 & 0.0841 & 0.2916 \\
\hline \multirow[t]{3}{*}{ D. spicata } & Plant & 0.0101 & $<0.0001$ & 0.2275 \\
\hline & Time & $<0.0001$ & $<0.0001$ & 0.0034 \\
\hline & Time*Plant & 0.4394 & 0.0053 & 0.4108 \\
\hline \multirow[t]{3}{*}{ P. australis } & Plant & 0.2273 & 0.1498 & 0.7211 \\
\hline & Time & $<0.0001$ & $<0.0001$ & 0.0002 \\
\hline & Time*Plant & 0.3148 & 0.0268 & 0.9875 \\
\hline \multirow[t]{3}{*}{ S. californicus } & Plant & 0.4810 & 0.9368 & 0.9261 \\
\hline & Time & $<0.0001$ & $<0.0001$ & $<0.0001$ \\
\hline & Time*Plant & 0.9794 & 0.0166 & 0.4838 \\
\hline
\end{tabular}

The model effect "Plant" indicates the identity of individual plants within a species, and the effect "Time*Plant" indicates the interaction between the main model effects of Time and Plant

Significance values of factors (main or interaction) examined for effects on response variables are indicated with bold font

negligible in P (Fig. 5). Spartina patens occurred only in R, where it displayed an overall pattern of decreasing cover over time. Cover of $S$. patens in R was significantly lower at the

Table 2 Results of a repeated measures analysis of variance of interspecific growth variation among four planted wetland macrophytes: Bolboschoenus robustus, Distichlis spicata, Phragmites australis, and Schoenoplectus californicus

\begin{tabular}{llllll}
\hline Variable & Model Effect & df Num & df Den & F & $P>$ F \\
\hline Cover $(\%)$ & Species & 3 & 20 & 37.64 & $<0.0001$ \\
& Time & 5 & 20 & 30.93 & $<0.0001$ \\
& Species*Time & 15 & 20 & 17.99 & $<\mathbf{0 . 0 0 0 1}$ \\
Percent of total & Species & 3 & 20 & 36.42 & $<0.0001$ \\
cover & Time & 5 & 20 & 223.98 & $<0.0001$ \\
& Species*Time & 15 & 20 & 29.02 & $<\mathbf{0 . 0 0 0 1}$ \\
Maximum & Species & 3 & 20 & 172.58 & $<0.0001$ \\
height (cm) & Time & 5 & 20 & 128.59 & $<0.0001$ \\
& Species*Time & 15 & 20 & 41.11 & $<\mathbf{0 . 0 0 0 1}$ \\
Maximum & Species & 3 & 15 & 104.95 & $<\mathbf{0 . 0 0 0 1}$ \\
lateral spread & Time & 3 & 3 & 20.09 & $\mathbf{0 . 0 1 7 3}$ \\
& Species*Time & 9 & 1 & 0.34 & 0.8771 \\
Stem number & Species & 3 & 20 & 25.32 & $<0.0001$ \\
& Time & 3 & 20 & 28.81 & $<0.0001$ \\
& Species*Time & 9 & 20 & 16.83 & $<\mathbf{0 . 0 0 0 1}$ \\
& Species & 3 & 20 & 29.56 & 0.0005 \\
Mean stem height & Time & 3 & 20 & 9.35 & $<0.0001$ \\
& Species*Time & 9 & 20 & 25.32 & $<\mathbf{0 . 0 0 0 1}$ \\
& & & &
\end{tabular}

Bold font indicates the significant main factors or highest-order interactions examined for effect on the response variable conclusion of the experiment (12.52 $\pm 9.32 \%)$ compared to July of the first growing season $(40.56 \pm 25.27 \%)$; the dominant cover species in $\mathrm{R}$ at the end of the experiment was D. spicata $(40.50 \pm 19.22 \%)$ (Table S2). Bare ground initially differed among the treatments $(\mathrm{R}[9.62 \pm 2.98 \%]<\mathrm{P}[61.94 \pm$ $2.70 \%]<\mathrm{NP}[88.00 \pm 0.00 \%]$, Table 3$)$. These differences were no longer present at the conclusion of the study (R, $13.23 \pm 6.97 \%$; P, $5.82 \pm 3.67 \%$; NP, $17.88 \pm 5.13 \%$ ).

Total stem number was significantly lower in NP $(0.27 \pm$ $0.21)$ than in $\mathrm{P}(7.45 \pm 0.41)$ in September of the first growing season; at all other measurement times, however, stem number was equivalent among the treatments. Mean stem height was also lower in NP $(0.84 \pm 0.68 \mathrm{~cm})$ than in $\mathrm{P}(59.95 \pm 6.75 \mathrm{~cm})$ in September of the first growing season. In April of the second growing season mean height was lower in NP (8.04 \pm $3.72 \mathrm{~cm})$ than in $\mathrm{P}(90.79 \pm 12.01 \mathrm{~cm})$ and $\mathrm{R}(51.55 \pm$ $3.33 \mathrm{~cm})$. In September of the second growing season there were no significant differences among treatments, but by April of the third growing season stem height in P (152.19 \pm $15.77 \mathrm{~cm})$ exceeded that in $\mathrm{R}(45.18 \pm 0.58 \mathrm{~cm})$ and $\mathrm{NP}$ $(57.09 \pm 6.09 \mathrm{~cm})$.

The Sørensen index identified low similarity between all treatment comparisons at both times examined (Table 4). Similarity based on presence/absence data tended to be higher than that based on cover data. ANOMSIM and MRPP analyses indicated the treatments were significantly different $(P<0.0001$, all comparisons). Three species $-D$. spicata, S. alterniflora, and Symphyotrichum tenuifolium - were found in all treatments at the conclusion of the study (Table S2). Belowground biomass differed by treatment $(P<0.0001)$; 
Fig. 2 Lateral spread (cm) of planted species measured from the center of a $1 \mathrm{~m}^{2}$ quadrat. Bars indicate the standard error of the mean values

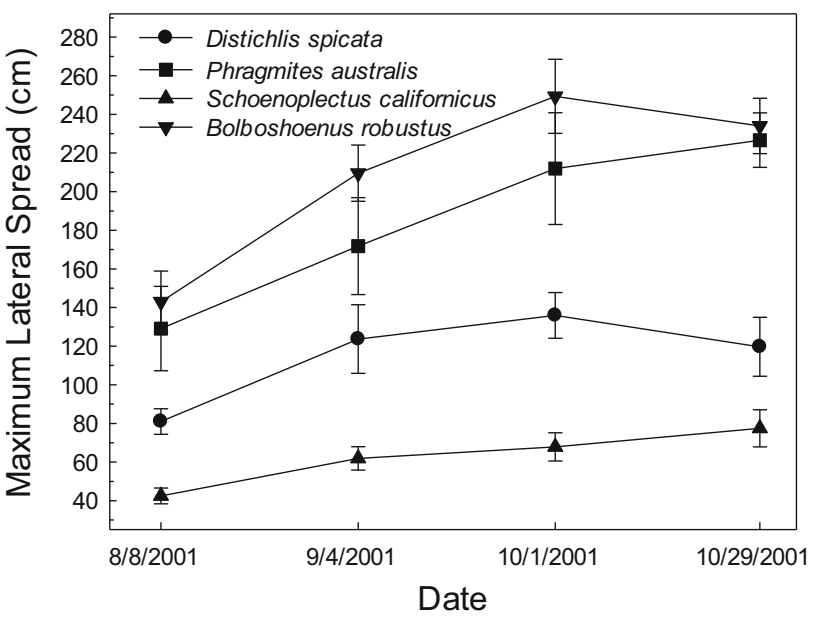

biomass in $\mathrm{P}(16.19 \pm 1.62 \mathrm{~g})$ and $\mathrm{R}(17.27 \pm 4.74 \mathrm{~g})$ were equivalent, and exceeded the value in NP $(3.78 \pm 0.72 \mathrm{~g})$.

\section{Salinity and Soil Characteristics}

Surface water salinity ranged between 1.2 and 9.3 psu during the study, and no treatment differences were found $(P=0.3850)$. Variation in surface salinity occurred over time $(P<0.0001)$. Interstitial water was difficult to collect at the sedimentaddition sites, resulting in an insufficient number of data points for analysis. Values for interstitial water salinity ranged from 1.2 to $13.0 \mathrm{psu}$. Soil bulk density varied among treatments in the upper 10-cm soil layer at both measurement times $(P=0.0037$, July 2001; $P<0.0001$, March 2003); this property was higher at $\mathrm{NP}$ and $\mathrm{P}$ than at R (Table 5a). Percent organic matter also varied in the upper $10 \mathrm{~cm}$ soil layer at both times $(P=0.0115$, July 2001; $P=0.0003$, March 2003), and was higher in R compared to NP and P (Table 5b). No treatment differences in soil sand, silt, or clay content were identified.

\section{Sedimentation and Elevation Change}

The depth to resistance for steel rod placement during RSET installation varied between 14.6 and $18.3 \mathrm{~m}$. Significant accretion was measured at all treatments, while only P displayed significant VLMw (i.e., an increase in elevation) (Table 6). Positive subsurface change, indicating subsidence, was documented at all treatments (Table 6). Treatment comparisons identified no differences in accretion $(P=0.2071)$ or subsidence $(P=0.3919)$. However, a significant difference was found for VLMw $(P=0.0186)$; elevation change at $\mathrm{P}$ was greater than that at $\mathrm{R}$. Elevation change at NP was intermediate compared to $\mathrm{P}$ and $\mathrm{R}$, and did not differ from either (Table 6).

\section{Discussion}

Sediment addition to the degraded marsh at Bayou Dupont raised soil surface elevations in interior ponded areas to levels that supported the growth of emergent marsh macrophytes, and the plant communities that established persisted throughout our 23-month study. The manipulation of plant succession through plantings revealed interesting insights concerning the utility of such plantings in coastal wetland restoration. We documented intraspecific growth variation in three of the planted species $-D$. spicata, $P$. australis, and $S$. californicus - during the first growing season following planting. These findings are consistent with results from greenhouse (Vasquez et al. 2005; Howard and Rafferty 2006; Howard 2010), and field (Seliskar and Gallagher 2000) studies. The relative magnitude of intraspecific variation found, however, was low. The difference in cover value between two $D$. spicata individuals had little practical significance; cover of those two overlapped with the other individuals, resulting in a lack of a plant with consistently greater growth. The intraspecific differences in P. australis and S. californicus responses also had minor biological significance; again, an individual plant that displayed consistently greater growth was not identified. Therefore, the data provide little support for a conclusion that intraspecific variation influenced plant community structure. It should be noted, however, that environmental conditions at the study area apparently imposed little stress, as evidenced by the lack of mortality and rapid spread of the planted species. Surface water salinity at the study sites was less than $10 \mathrm{psu}$, which is within the normal range for these intermediate to brackish marsh species, and there was no evidence of extended flooding (e.g., no water marks on unit support posts). Greenhouse studies that identified higher degrees of intraspecific growth variation in these species imposed salinity up to 
Fig. 3 Planted species (a) relative percent of cover (i.e., percent of total cover that is the planted species) and (b) maximum stem height $(\mathrm{cm})$. Bars indicate the standard error of the mean values
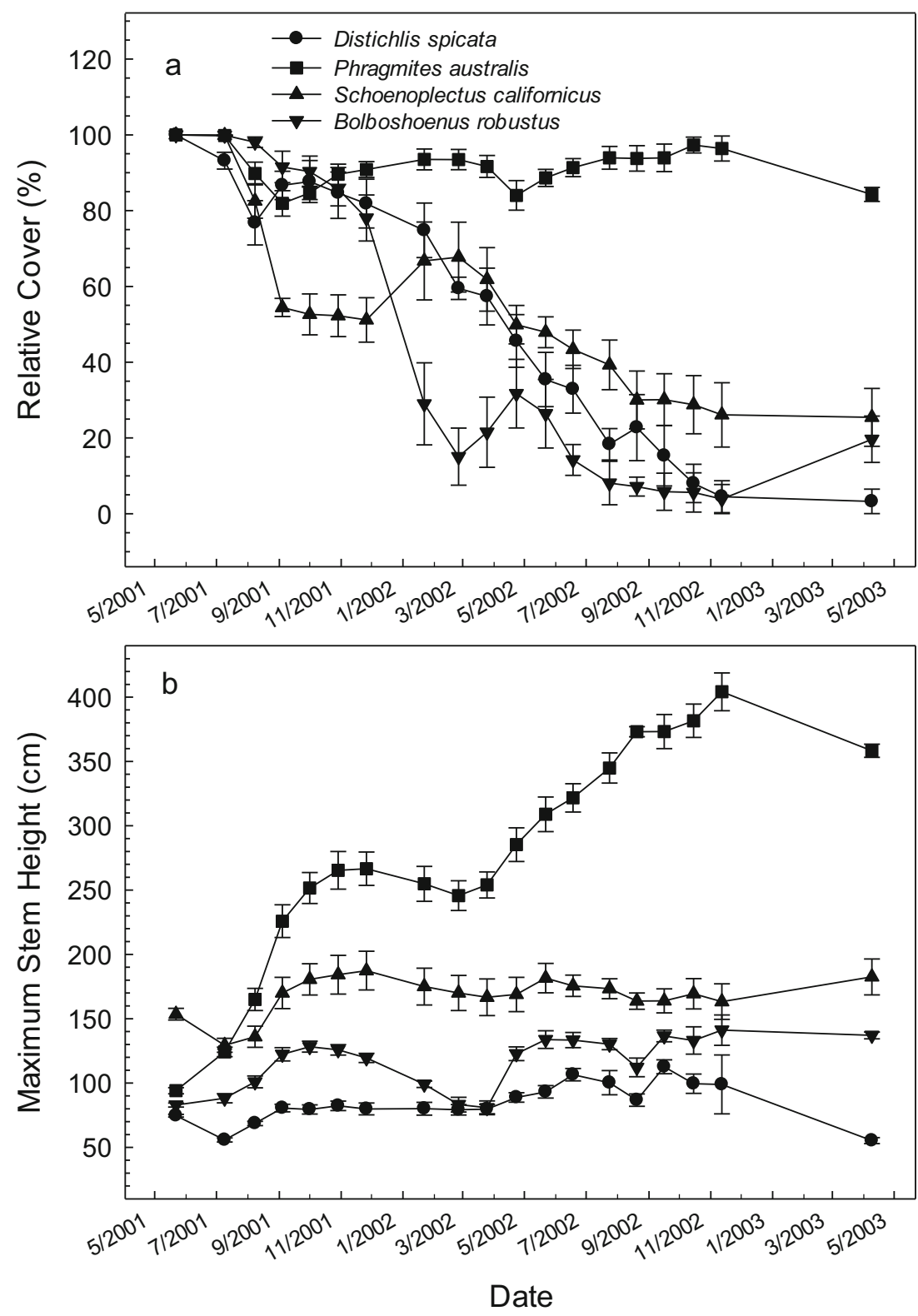

25 psu and continual flooding (Howard and Rafferty 2006; Howard 2010). We recognize that strength of our conclusions regarding the role of intraspecific variation in structuring plant communities is limited by the lack of genetic analyses confirming the presence of different genets of the plants studied (but, see below for an exception concerning $P$. australis). Our assumption that the individual plants collected represented separate genets within a species may not have reflected actual conditions. We believe, however, that the assumption of intraspecific variation among the plants was reasonable based on studies that have indicated high levels of genetic diversity in clonal wetland plants (e.g., Richards et al. 2004).

Although intraspecific variation identified among the planted species was of little consequence during initial community establishment, competitive variation among
$P$. australis individuals was noted during the course of the study. After this experiment was initiated, information was published describing the presence of an invasive Eurasian lineage of $P$. australis in North America (Saltonstall 2002). Genetic analyses of specimens from our original plant collection revealed that, of the six $P$. australis individuals planted, three were the Eurasian haplotype $M$ and three were haplotype I (Howard et al. 2008). The later lineage is also found in South America and Asia, and genetic analyses by Lambertini et al. (2012) indicated it is related to the African species Phragmites mauritianus. While we planted the two lineages at about the same density, genetic analyses of plant tissues collected in the middle of the second growing season revealed that haplotype $\mathrm{M}$ plants had become dominant and represented between $67 \%$ and $100 \%$ of the plants sampled (Howard et al. 2008). The 
Fig. 4 Mean (a) total cover (\%) and (b) species richness over time by treatment (not planted, planted, reference). Bars indicate the standard error of the means

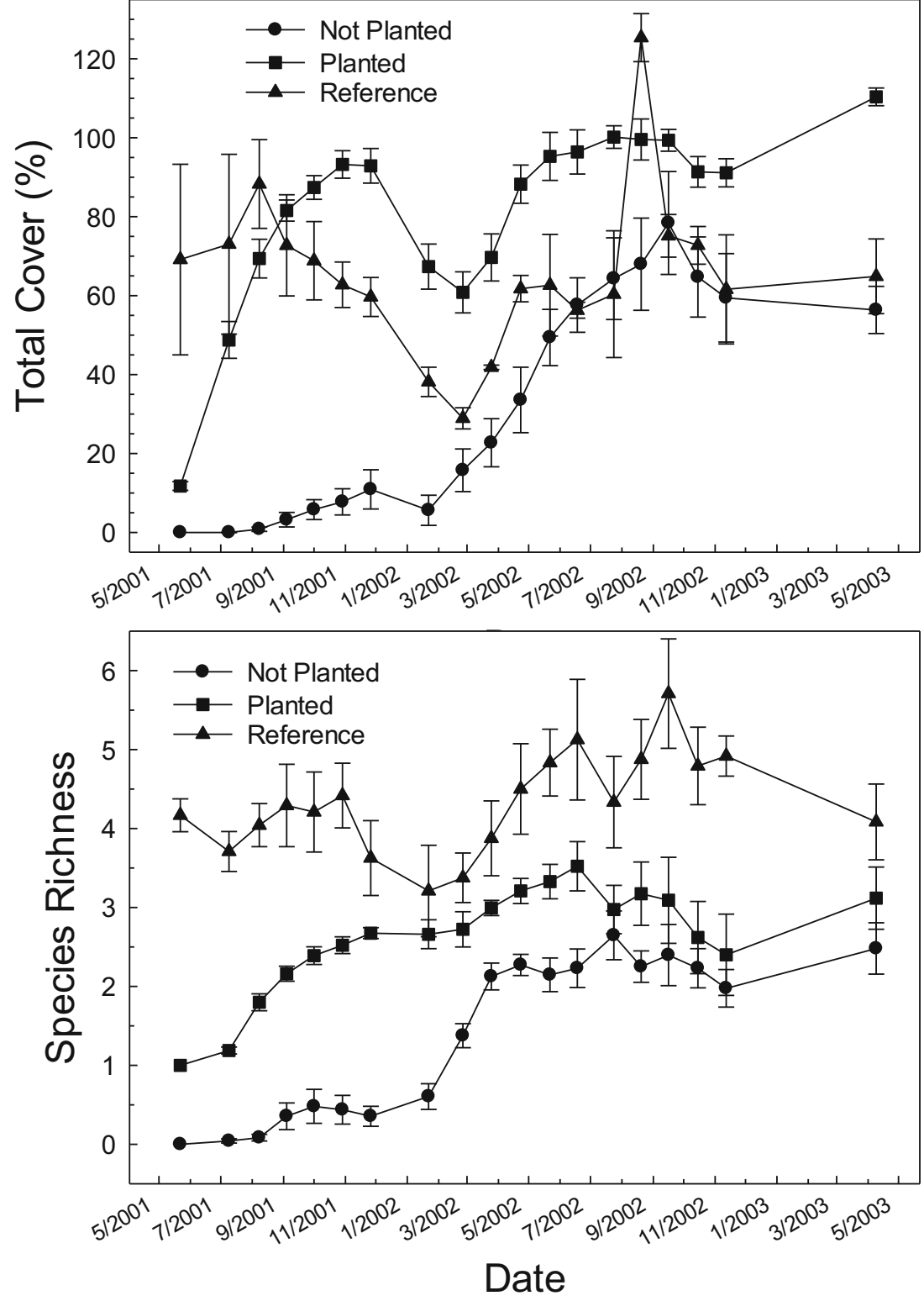

superior competitive performance of the $\mathrm{M}$ haplotype identified conflicts with findings from a common garden study conducted in freshwater conditions with individually potted plants (Mozdzer et al. 2016). In that study, haplotype I had greater total, aboveground, and belowground biomass and maximum stem height compared to haplotype $\mathrm{M}$, but lower stem density (Mozdzer et al. 2016). The difference between that study and ours may be related to the exclusion of competitive interactions in the greenhouse study. Several studies have documented greater growth in haplotype $\mathrm{M}$ compared to native lineages of $P$. australis (e.g., Vasquez et al. 2005; League et al. 2006; Price et al. 2014).

Regarding our second question related to the effects of interspecific variation, we found a major influence on plant community composition and structure at P. Two species, $B$. robustus and $P$. australis, spread most rapidly during the initial few months of the study. A contraction in the spread of $B$. robustus and D. spicata at the end of the first growing season (Fig. 2) may have indicated the onset of winter senescence. In September, five months after planting, it became apparent that $P$. australis was displacing the other planted species. Although not verified experimentally, the mechanisms for the superior competitive ability of $P$. australis were likely its greater mean height $(1.65 \mathrm{~m})$, leading to light limitation on growth of the shorter species, and prolific belowground production, as documented in other studies (League et al. 2006; Moore et al. 2012; Mozdzer and Megonigal 2012). The competitive interactions between plant species at the restoration site may have been affected by salinity and nutrient dynamics. The surface water salinity measured, which was consistently lower than 10 psu, likely provided conditions more favorable to the growth of 


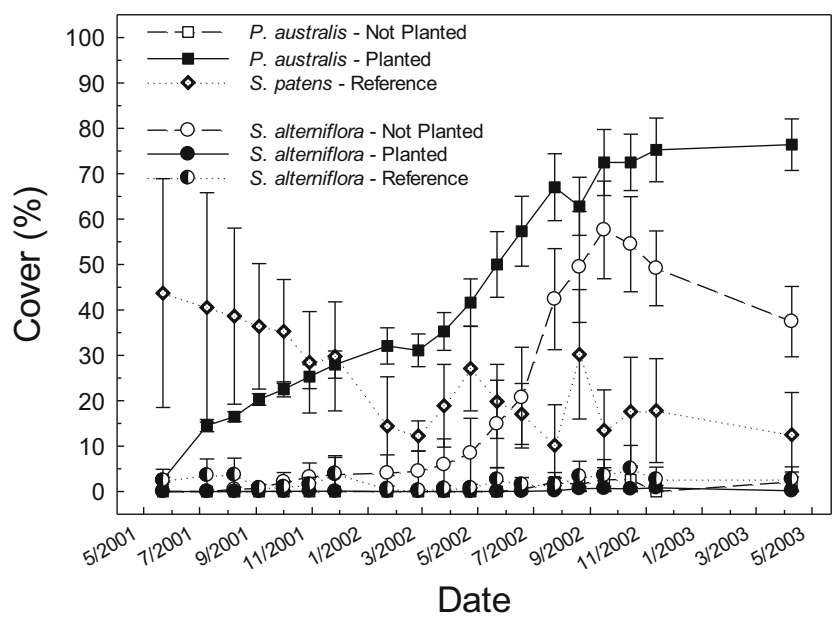

Fig. 5 Mean cover of common species by treatment (not planted, planted, reference). Species are Phragmites australis (Phau), Spartina patens (Sppa), and Spartina alterniflora (Spal). Phragmites australis was not present in the reference treatment, while $S$. patens occurred only in the reference treatment. Bars indicate the standard error of the means

P. australis, a species adapted to low to moderate salinity, than to B. robustus and D. spicata, which are tolerant of moderate to high salinity. The restoration site is located in the Mississippi River Deltaic Plain, where nutrient loading through agricultural activities and urbanization have altered water quality over the past two centuries (Turner and Rabalais 2003). We did not measure soil and water nutrient levels, but these factors can have a strong influence on interactions between plant species (Zedler and Kercher 2004). The invasive $P$. australis lineage was noted to have greater floret and inflorescence production compared to native lineages under elevated nutrient conditions (Kettenring et al. 2011), and eutrophication played a central role in the expansion of invasive $P$. australis along the northeastern Atlantic coast of the United States (Holdredge et al. 2010). Nutrient enrichment, therefore, may have been an additional factor promoting $P$. australis growth at our sites.

Aerial imagery of the restoration site showed that $P$. australis was present in large patches eight years after planting, and that percent cover increased up to 22 times over six years (Howard and Turluck 2013). The fact that we intentionally planted $P$. australis at the restoration site may be viewed as controversial by restoration ecologists based on the invasive nature of the non-native lineages. The ecosystem impacts

Table 3 Results of a repeated measures analysis of variance examining differences among three marsh treatments (Trt): not-planted dredge sites, planted dredge sites, and reference sites not affected by dredge application

\begin{tabular}{|c|c|c|c|c|c|}
\hline Variable & Model Effect & df Num & df Den & $\mathrm{F}$ & $P>\mathrm{F}$ \\
\hline \multirow[t]{3}{*}{ Total cover } & Trt & 2 & 12 & 62.53 & $<0.0001$ \\
\hline & Time & 5 & 12 & 20.35 & $<0.0001$ \\
\hline & Trt*Time & 10 & 12 & 18.34 & $<0.0001$ \\
\hline \multirow[t]{3}{*}{ Species richness } & Trt & 2 & 12 & 27.98 & $<0.0001$ \\
\hline & Time & 5 & 12 & 47.91 & $<0.0001$ \\
\hline & Trt*Time & 10 & 12 & 9.95 & 0.0002 \\
\hline \multirow[t]{3}{*}{ Phragmites australis cover } & Trt & 2 & 12 & 154.28 & $<0.0001$ \\
\hline & Time & 5 & 59 & 7.70 & $<0.0001$ \\
\hline & Trt*Time & 10 & 59 & 3.67 & 0.0008 \\
\hline \multirow[t]{3}{*}{ Spartina alterniflora cover } & Trt & 2 & 12 & 19.74 & 0.0002 \\
\hline & Time & 5 & 59 & 7.68 & $<0.0001$ \\
\hline & Trt*Time & 10 & 59 & 8.46 & $<0.0001$ \\
\hline \multirow[t]{3}{*}{ Spartina patens cover } & Trt & 2 & 12 & 13.92 & 0.0007 \\
\hline & Time & 5 & 59 & 4.25 & 0.0023 \\
\hline & Trt*Time & 10 & 59 & 3.41 & 0.0014 \\
\hline \multirow[t]{3}{*}{ Bare ground } & Trt & 2 & 12 & 42.52 & $<0.0001$ \\
\hline & Time & 5 & 12 & 34.05 & $<0.0001$ \\
\hline & Trt*Time & 10 & 12 & 12.56 & $<0.0001$ \\
\hline \multirow[t]{3}{*}{ Stem number } & Trt & 2 & 12 & 0.26 & 0.7763 \\
\hline & Time & 3 & 12 & 11.52 & 0.0008 \\
\hline & Trt*Time & 5 & 12 & 53.27 & $<0.0001$ \\
\hline \multirow[t]{3}{*}{ Mean height } & Trt & 2 & 12 & 39.94 & $<0.0001$ \\
\hline & Time & 3 & 12 & 93.45 & $<0.0001$ \\
\hline & Trt*Time & 5 & 12 & 9.32 & 0.0008 \\
\hline
\end{tabular}

Bold font indicates the significant main factors or highest-order interactions examined for effect on the response variable 
Table 4 Sørensen similarity coefficient based on presence/absence (Presence) and percent cover (Cover) between treatments at two times

\begin{tabular}{llllll}
\hline & \multicolumn{2}{l}{ August 2002 } & & & April 2003 \\
\cline { 2 - 3 } \cline { 6 - 7 } Treatments Compared & Presence & Cover & & Presence & Cover \\
\hline Planted, Not-planted & 0.42 & 0.11 & & 0.34 & 0.18 \\
Planted, Reference & 0.29 & 0.14 & 0.34 & 0.02 \\
Not-planted, Reference & 0.18 & 0.04 & & 0.26 & 0.11 \\
\hline
\end{tabular}

Cover values are the mean per species per treatment. Coefficient values range from 0 (complete dissimilarity) to 1 (total similarity)

of $P$. australis are often described as negative, and include reduced species richness and altered nutrient cycling (reviewed in Meyerson et al. 2000). Native P. australis is considered to be threatened along the Atlantic coast of the United States because it is being displaced by the invasive lineage (Meadows and Saltonstall 2007). Other studies, however, have identified positive ecosystem effects, including high rates of carbon sequestration and soil stabilization (reviewed in Kiviat 2013). In Louisiana P. australis is considered to be a native species. An early vegetation survey of southeastern Louisiana wetlands noted that Phragmites communis (syn. P. australis) was a typical species in the "cane zone", often as a co-dominant in association with Spartina cynosuroides (Penfound and Hathaway 1938). By the late 1960 's, P. communis was described as a dominant species in both fresh and brackish marshes of the Mississippi River Delta (MRD) (Chabreck and Palmisano 1973), and analyses of

Table 5 Soil bulk density (a) and organic matter content (b) by soil depth and treatment at study sites in Barataria Basin, southeast Louisiana at two dates

\begin{tabular}{|c|c|c|c|c|}
\hline \multirow[b]{2}{*}{ Date } & \multirow[b]{2}{*}{ Soil Depth } & \multicolumn{3}{|l|}{ Treatment } \\
\hline & & Not-planted & Planted & Reference \\
\hline \multicolumn{5}{|c|}{ a. Bulk density $\left(\mathrm{g} \mathrm{cm}^{-3}\right)$} \\
\hline \multirow[t]{3}{*}{ July 2001} & $0-10 \mathrm{~cm}$ & $0.36(0.04)^{\mathrm{a}}$ & $0.40(0.03)^{\mathrm{a}}$ & $0.17(0.03)^{\mathrm{b}}$ \\
\hline & $10-20 \mathrm{~cm}$ & $0.30(0.04)$ & $0.28(0.01)$ & $0.36(0.25)$ \\
\hline & $20-30 \mathrm{~cm}$ & $0.27(0.03)$ & $0.27(0.02)$ & $0.39(0.27)$ \\
\hline \multirow[t]{3}{*}{ March 2003} & $0-10 \mathrm{~cm}$ & $0.36(0.02)^{\mathrm{a}}$ & $0.37(0.02)^{\mathrm{a}}$ & $0.15(0.02)^{\mathrm{b}}$ \\
\hline & $10-20 \mathrm{~cm}$ & $0.33(0.06)$ & $0.37(0.07)$ & $0.30(0.19)$ \\
\hline & $20-30 \mathrm{~cm}$ & $0.31(0.04)$ & $0.28(0.03)$ & $0.36(0.25)$ \\
\hline \multicolumn{5}{|c|}{ b. Organic matter (\%) } \\
\hline \multirow[t]{3}{*}{ July 2001} & $0-10 \mathrm{~cm}$ & $23.70(1.90)^{\mathrm{a}}$ & $22.57(2.89)^{\mathrm{a}}$ & $38.37(4.18)^{\mathrm{b}}$ \\
\hline & $10-20 \mathrm{~cm}$ & $21.33(1.55)$ & $21.21(1.20)$ & $32.20(15.11)$ \\
\hline & $20-30 \mathrm{~cm}$ & $24.05(2.61)$ & $21.38(2.20)$ & $28.61(14.37)$ \\
\hline \multirow[t]{3}{*}{ March 2003} & $0-10 \mathrm{~cm}$ & $22.93(1.89)^{\mathrm{a}}$ & $22.60(1.79)^{\mathrm{a}}$ & $42.00(4.25)^{\mathrm{b}}$ \\
\hline & $10-20 \mathrm{~cm}$ & $20.64(2.93)$ & $17.86(3.10)$ & $36.82(13.07)$ \\
\hline & $20-30 \mathrm{~cm}$ & $19.23(2.84)$ & $21.72(3.51)$ & $34.52(17.08)$ \\
\hline
\end{tabular}

Data are the mean values (standard error). Different letters within a row indicate significant $(P<0.05)$ treatment differences survey data from 1968 documented the occurrence of P. australis across the Barataria Basin (Visser et al. 1998). As noted previously, when the experiment was initiated in 2001 information on the existence of invasive, non-native lineages of $P$. australis had not yet been published. Because our goal was to encourage the development of a plant community that would be resilient under stressful conditions along the Louisiana coast (i.e., high subsidence and rapid sea-level rise), $P$. australis was considered a reasonable candidate for inclusion in the study based on its characteristics of readily trapping sediments and contributing to elevation gain (Rooth and Stevenson 2000). In addition to having high competitive ability, $P$. australis has been described as very resilient and capable of maintaining vigor in stressed ecosystems (Hershner and Havens 2008), attributes that may be considered desirable in coastal areas threatened by rising sea levels. Lambertini et al. (2012) confirmed that invasive $P$. australis lineages are now dominant in the MRD. A recent dieback of $P$. australis in the MRD has generated widespread concern over wetland loss because dead stands have often converted to open water (Knight et al. 2018). This highlights a situation where, although invasive, $P$. australis is providing critical ecosystem services in the form of storm protection and wildlife habitat.

Marsh treatment comparisons revealed significant differences in plant communities composition and structure. Colonization at NP was slow during the first growing season, with mean cover of just $5.80 \pm 2.52 \%$ in early October, 14 months following sediment addition. This low establishment rate was likely the result of a depauperate seed bank, which has been noted for other restored wetlands (Morzaria-Luna and Zedler 2007). Also, it is unlikely that rhizome fragments of clonal marsh species were present in the sediments added to the degraded marsh because those sediments were dredged from the bottom of the adjacent canal. Rapid colonization (within six months) in a New Jersey salt marsh restored with sediment addition was attributed to rhizome recruitment (VanZomeren et al. 2018). At our site, S. alterniflora was the primary colonizing species and initially established during the first growing season through seed germination. Active seed dispersal mechanisms have been noted for $S$. alterniflora in Louisiana (Utomo et al. 2009), with wind as the primary means for local dispersal (Elsey-Quirk et al. 2009). Salt marsh restoration using sediment addition has been noted to increase sexual reproductive capacity in S. alterniflora at the patch scale (Jones et al. 2019). Other plants that established at NP during the first growing season were Elodea canadensis, Eleocharis sp., and Paspalum sp. The only planted species found at $\mathrm{R}$ was $D$. spicata. We did not conduct a vegetation survey in the vicinity of the restored sites, so it is not known if the other planted species were initially present as possible nearby seed sources. However, three of the planted species - B. robustus, D. spicata, and P. australis established at NP during the second growing season, likely through both seed germination and vegetative propagation. 
Table 6 Soil surface vertical accretion, vertical land motion (VLMw), and estimated rate of subsurface change over two years

\begin{tabular}{|c|c|c|c|c|c|c|}
\hline \multirow[b]{2}{*}{ Treatment } & \multicolumn{2}{|c|}{ Vertical Accretion } & \multicolumn{2}{|l|}{$\mathrm{VLM}_{\mathrm{W}}$} & \multicolumn{2}{|c|}{ Subsurface Change $^{1}$} \\
\hline & $\mathrm{mm} \mathrm{y}^{-1}$ & $P$ & $\mathrm{~mm} \mathrm{y}^{-1}$ & $P$ & $\mathrm{~mm} \mathrm{y}^{-1}$ & $P$ \\
\hline Not planted & $24.07 \pm 2.44^{\mathrm{a}}$ & $<0.0001$ & $0.25 \pm 1.10^{\mathrm{ab}}$ & 0.8216 & $23.44 \pm 2.28^{\mathrm{a} 2}$ & $<0.0001$ \\
\hline Planted & $23.23 \pm 1.99^{\mathrm{a}}$ & $<0.0001$ & $4.17 \pm 0.91^{\mathrm{a}}$ & 0.0001 & $19.06 \pm 2.22^{\mathrm{a}}$ & $<0.0001$ \\
\hline Reference & $18.66 \pm 2.47^{\mathrm{a}}$ & $<0.0001$ & $-2.95 \pm 2.64^{\mathrm{b}}$ & 0.2761 & $21.61 \pm 2.19^{\mathrm{a}}$ & $<0.0001$ \\
\hline
\end{tabular}

Data are listed by marsh treatment at study sites in Barataria Basin, southeast Louisiana. Subsurface change was calculated by subtracting VLM $\mathrm{W}_{\mathrm{W}}$ from vertical accretion. Different letters within columns for vertical accretion, VLMw, and subsurface change indicate significant $(P<0.05)$ treatment differences

${ }^{1}$ Positive values indicate shallow subsidence (Cahoon 2015)

${ }^{2}$ When determining subsurface change, the regression model was adjusted for missing values

Rapid growth of $S$. alterniflora and other colonizing species through the second growing season resulted in equivalent total cover at NP and the other treatments at the conclusion of experiment. A similar 2-year time frame for cover equivalency was found at Louisiana salt marsh restoration areas (Mendelssohn and Kuhn 2003; Schrift et al. 2008). Sediment additions that raised elevation $2-11 \mathrm{~cm}$ above MSL were identified as supporting marsh stability, with additions above the $11 \mathrm{~cm}$ threshold leading to decreased stability (Stagg and Mendelssohn 2011). Elevation at the Bayou Dupont site was initially raised $15 \mathrm{~cm}$ above the surrounding intact marsh; plant establishment and growth documented during our study indicates that surface elevation was decreased to a suitable range, probably through soil compaction over time.

Despite similar final total cover values between marsh treatments, Sørensen similarity and ANOSIM analyses revealed that species composition varied among the treatments. Dominant plant species at the experiment's conclusion were $S$. alterniflora, $P$. australis, and D. spicata in NP, P, and R, respectively. The declining trend in $S$. alterniflora cover at the end of the second growing season at NP (Fig. 5) was likely due to its replacement by species with greater competitive ability at the moderate salinity levels that characterized the study site. The initial dominant species at $\mathrm{R}$ was $S$. patens, and the reason for the shift to D. spicata is unknown. Both are typical high marsh species and have similar patterns of aboveground and belowground biomass allocation; however, D. spicata has superior colonizing ability compared to $S$. patens (Brewer et al. 1998a). Distichlis spicata responded positively to wrack disturbance while $S$. patens responded negatively (Brewer et al. 1998b). The species shift we documented may therefore be related to disturbance (e.g., hurricane effects). Belowground biomass was lower at not-planted compared to planted and reference sites. This is consistent with a study that found belowground biomass at a restored salt marsh remained lower than that at reference sites seven years following sediment addition (Tong et al. 2013). Similarly, seven years were required before belowground biomass in restored brackish- marsh ponds approached that of reference marshes (La Peyre et al. 2009).

Properties of the sediment used for wetland restoration have an important influence on restoration outcome (Mendelssohn and Kuhn 2003; Kongchum et al. 2017; VanZomeren et al. 2018). We found differences in soil bulk density and organic matter between marsh treatments, but those differences occurred only in the top 10-cm layer. The reference marsh had lower bulk density and higher organic matter content compared to sediment-addition marshes. This was expected because plants contribute organic material to the soil over time, reducing soil bulk density. Surface bulk density in R was higher than the $0.08-0.11 \mathrm{~g} \mathrm{~cm}^{-3}$ range identified in a degrading Louisiana brackish marsh (Nyman et al. 1994). In salt marshes, bulk density below 0.20 has been identified as a threshold below which growth of S. alterniflora is not supported (DeLaune et al. 1990). The increase in bulk density at our site resulting from sediment addition likely improved conditions for plant growth.

Vertical accretion and subsurface change were significant at all treatments. We did not document treatment variation in accretion or subsurface change, but soil surface elevation differences were found. Because surface elevation did not change at $\mathrm{R}$ and NP, accretion compensated for the significant subsidence that occurred. In contrast, elevation increased at planted sites. As previously noted, $P$. australis, a species that can generate high root and rhizome biomass, became dominant at the planted sites. It can be concluded that growth of $P$. australis belowground structures drove root zone expansion at planted sites. The contribution of $P$. australis to soil processes was also noted in Chesapeake Bay in Maryland, USA, where the large amount of surface litter in a $P$. australis stand acted to trap organic and mineral matter; the vertical accretion rate was found to be $3-4 \mathrm{~mm} \mathrm{yr}^{-1}$ greater in the P. australis stand than in adjacent stands of Typha spp. and Panicum virgatum (Rooth et al. 2003). If $P$. australis continues to spread aggressively at the Bayou Dupont restoration site, it is expected that this species will have a significant impact on soil surface elevation dynamics over time. 


\section{Conclusions}

We identified a strong influence of interspecific variation on plant community composition and structure in the restored marsh at Bayou Dupont in southeast Louisiana. The planted sites became dominated by $P$. australis, likely a result of the unintended planting of an invasive lineage. The presence of invasive $P$. australis, which is considered undesirable by many ecologists, makes forming conclusions concerning the efficacy of planting problematic. We do not know if the positive results of rapidly-increasing cover and increased surface elevation would have occurred in the absence of invasive $P$. australis. Cover at not-planted sites was equivalent to that at reference sites after two years, so the labor-intensive and costly practice of transplanting rooted plants may be considered unnecessary. In addition, dissimilarity of plant communities between the treatments may be a concern. The primary species that naturally colonized the sediment-addition sites, S. alterniflora, had relatively low cover at the reference sites. It is probable that competitive interactions will lead to species replacement over time and increase the similarity between not-planted and reference sites; this trajectory, however, is contingent on marsh elevation gain exceeding the rate of sea-level rise. In contrast, the dominance of invasive $P$. australis at planted sites precludes the possibility that these sites will transition over time to more closely resemble the species assemblage at reference sites. Finally, geomorphic setting may be an important consideration when determining if planting is advantageous. Plantings that rapidly increase cover and increase elevation may serve a critical role in wetland restoration if natural colonization is slow under conditions of high subsidence and rising sea levels, such as occur in coastal Louisiana.

Acknowledgements Funding for this study was provided by the Louisiana Department of Natural Resources, Agreement No. 2503-9836, and the U.S. Geological Survey Ecosystems Mission Area. We appreciate program support from Kenneth Bahlinger, and assistance in the field and data entry provided by Brian Briggs, Timothy Daigle, Natalie Kliningsmith, Troy Olney, Brian Perez, Lane Rivenbark, Brad Segura, and Jason Sullivan. Comments from Camille Stagg and two anonymous reviewers helped to improve this manuscript. Any use of trade, firm, or product names is for descriptive purposes only and does not imply endorsement by the U.S. Government. The data are available at https://doi. org/10.5066/P9VGVX76 (Howard 2019).

Open Access This article is distributed under the terms of the Creative Commons Attribution 4.0 International License (http:// creativecommons.org/licenses/by/4.0/), which permits unrestricted use, distribution, and reproduction in any medium, provided you give appropriate credit to the original author(s) and the source, provide a link to the Creative Commons license, and indicate if changes were made.

\section{References}

Barko JW, Smart RM, Lee CR, Landin MC, Sturgis TC, Gordon RN (1977) Establishment and growth of selected freshwater and coastal marsh plants in relation to characteristics of dredged sediments. Technical report D-77-2, dredged material research program, U.S. Army Corps of Engineers waterway Experiment Station

Bass AS, Turner RE (1997) Relationship between salt marsh loss and dredged canals in three Louisiana estuaries. Journal of Coastal Research 13:895-903

Ben-Dor E, Banin A (1989) Determination of organic matter content in arid-zone soils using a simple loss-on-ignition method. Communication in Soil Science and Plant Analysis 20:1675-1695

Brewer JS, Bertness MD (1996) Disturbance and intraspecific variation in the clonal morphology of salt marsh perennials. OIKOS 77:107-116

Brewer JS, Rand T, Levine JM, Bertness MD (1998a) Biomass allocation, clonal dispersal, and competitive success in three salt marsh plants. OIKOS 82:347-353

Brewer JS, Levine JM, Bertness MD (1998b) Interactive effects of elevation and burial with wrack on plant community structure in some Rhode Island salt marshes. Journal of Ecology 86:125-136

Brix H (1999) Genetic diversity, ecophysiology and growth dynamics of reed (Phragmites australis). Aquatic Botany 64:179-184

Broome SW, Seneca ED, Woodhouse WW Jr (1988) Tidal salt marsh restoration. Aquatic Botany 32:1-22

Cahoon DR (2015) Estimating relative sea-level rise and submergence potential at a coastal wetland. Estuaries and Coasts 38:1077-1084

Cahoon DR, Cowan JH Jr (1988) Environmental impacts and regulatory policy implications of spray disposal of dredged material in Louisiana wetlands. Coastal Management 16:341-361

Cahoon DR, Turner RE (1989) Accretion and canal impacts in a rapidly subsiding wetland II: feldspar marker horizon technique. Estuaries 12:260-268

Cahoon DR, Lynch JC, Perez BC, Segura B, Holland RD, Stelly C, Stephenson G, Hensel P (2002) High-precision measurements of wetland sediment elevation: II. The rod surface elevation table. Journal of Sedimentary Research 72:734-739

Chabreck RH (1972) Vegetation, water, and soil characteristics of the Louisiana coastal region. Louisiana State University Agricultural Experiment Station Bulletin No. 664. Louisiana State University, Baton Rouge

Chabreck RH, Palmisano AW (1973) The effects of hurricane Camille on the marshes of the Mississippi River Delta. Ecology 54:1118-1123

Craft C (2016) Creating and restoring wetlands: from theory to practice. Elsevier, Amsterdam

Croft AL, Leonard LA, Alphin TD, Cahoon LB, Posey MH (2006) The effects of thin layer sand renourishment on tidal marsh processes: Masonboro Island, North Carolina. Estuaries and Coasts 29:737750

DeLaune RD, Patrick WH Jr, Van Breemen N (1990) Processes governing marsh formation in a rapidly subsiding coastal environment. Catena 17:277-288

Edwards KR, Proffitt CE (2003) Comparison of wetland structural characteristics between created and natural salt marshes in Southwest Louisiana, USA. Wetlands 23:344-356

Elsey-Quirk T, Middleton BA, Proffitt CE (2009) Seed dispersal and seedling emergence in a created and a natural salt marsh on the 
Gulf of Mexico coast in Southwest Louisiana, U.S.a. Restoration Ecology 17:422-432

Elsey-Quirk T, Graham SA, Mendelssohn IA, Sneddon G, Day JW, Twilley RR, Shaffer G, Sharp LA, Pahl J, Lane RR (2019) Mississippi River sediment diversions and coastal wetland sustainability: synthesis of response to freshwater, sediment, and nutrient inputs. Estuarine, Coastal and Shelf Science 221:170-183

Evers DE, Sasser CE, Gosselink JG, Fuller DA, Visser JM (1998) The impact of vertebrate herbivores on wetland vegetation in Atchafalaya Bay, Louisiana. Estuaries 21:1-13

Ford MA, Grace JB (1998) Effects of vertebrate herbivores on soil processes, plant biomass, litter accumulation and soil elevation changes in a coastal marsh. Journal of Ecology 86:974-982

Haltiner J, Zedler JB, Boyer KE, Williams GD, Callaway JC (1997) Influence of physical processes on the design, functioning and evolution of restored tidal wetlands in California (USA). Wetlands Ecology and Management 4:73-91

Hershner C, Havens KJ (2008) Managing invasive aquatics in a changing system: strategic consideration of ecosystem services. Conservation Biology 22:544-550

Hester MW, Mendelssohn IA, McKee KL (1998) Intraspecific variation in salt tolerance and morphology in Panicum hemitomon and Spartina alterniflora (Poaceae). International Journal of Plant Science 159:127-138

Holdredge C, Bertness MD, von Wettberg E, Silliman BR (2010) Nutrient enrichment enhances hidden differences in phenotype to drive a cryptic plant invasion. Oikos 119:1776-1784

Howard RJ (2010) Intraspecific variation in growth in marsh macrophytes in response to salinity and soil type: implications for wetland restoration. Estuaries and Coasts 33:127-138

Howard RJ (2019) Plant community establishment in a coastal marsh restored using sediment additions, Barataria Basin, Louisiana. U.S. Geological Survey data release. https://doi.org/10.5066/ P9VGVX76

Howard RJ, Rafferty PS (2006) Clonal variation in response to salinity and flooding stress in four marsh macrophytes of the northern Gulf of Mexico, USA. Environmental and Experimental Botany 56:301313

Howard RJ, Turluck TD (2013) Phragmites australis expansion in a restored brackish marsh: documentation at different time scales. Wetlands 33:207-215

Howard RJ, Travis SE, Sikes BA (2008) Rapid growth of a Eurasian haplotype of Phragmites australis in a restored brackish marsh in Louisiana, USA. Biological Invasions 10:369-379

Hughes AR (2014) Genotypic diversity and trait variance interact to affect salt marsh performance. Journal of Ecology 102:651-658

Hughes AR, Lotterhos KE (2014) Genotypic diversity at multiple spatial scales in the foundation marsh species, Spartina alterniflora. Marine Ecology Progress Series 497:105-117

Hughes AR, Stachowicz JJ (2011) Seagrass genotypic diversity increases disturbance response via complementarity and dominance. Journal of Ecology 99:445-453

Ivey CT, Richards JH (2001) Genotypic diversity and clonal structure of everglades sawgrass, Cladium jamaicense (Cyperaceae). International Journal of Plant Science 162:1327-1335

Jones SF, Yando ES, Stagg CL, Hall CT, Hester MW (2019) Restoration affects sexual reproductive capacity in a salt marsh. Estuaries and Coasts 42:976-986

Kent M (2012) Vegetation description and data analysis, 2nd edn. WileyBlackwell, Chichester

Kettenring KM (2016) Viability, dormancy, germination, and intraspecific variation of Bolboschoenus maritimus (alkali bulrush) seeds. Aquatic Botany 134:26-30
Kettenring KM, McCormick MK, Baron HM, Whigham DF (2011) Mechanisms of Phragmites australis invasion: feedback among genetic diversity, nutrients, and sexual reproduction. Journal of Applied Ecology 48:1305-1313

Kiviat E (2013) Ecosystem services of Phragmites in North America with emphasis on habitat functions. AoB plants 5:plt008

Knight IA, Wilson BE, Gill M, Aviles L, Cronin JT, Nyman JA, Schneider SA, Diaz R (2018) Invasion of Nipponaclerda biwakoensis (Hemiptera: Acleridae) and Phragmites australis dieback in southern Louisiana, USA. Biological Invasions 20:27392744

Kongchum M, Materne MD, Williamson GB, Bissett L (2017) Effect of elevation on soil properties in reconstructed back barrier island coastal marsh using dredged materials. Wetlands 37:301-311

La Peyre MK, Gossman B, Piazza BP (2009) Short- and long-term response of deteriorating brackish marshes and open-water ponds to sediment enhancement by thin-layer dredge disposal. Estuaries and Coasts 32:390-402

Lambertini C, Mendelssohn IA, Gustafsson MHG, Olesen B, Riis T, Sorrell BK, Brix H (2012) Tracing the origin of gulf coast Phragmites (Poaceae): a story of long-distance dispersal and hybridization. American Journal of Botany 99:538-551

League MT, Colbert EP, Seliskar DM, Gallagher JL (2006) Rhizome growth dynamics of native and exotic haplotypes of Phragmites australis (common reed). Estuaries and Coasts 29:269-276

Lessmann JM, Mendelssohn IA, Hester MA, McKee KL (1997) Population variation in growth response to flooding of three marsh grasses. Ecological Engineering 8:31-47

Meadows RE, Saltonstall K (2007) Distribution of native and introduced Phragmites australis in freshwater and oligohaline tidal marshes of the Delmarva Peninsula and southern New Jersey. Journal of the Torrey Botanical Society 134:99-107

Mendelssohn IA, Kuhn NL (2003) Sediment subsidy: effects on soilplant responses in a rapidly submerging coastal salt marsh. Ecological Engineering 21:115-128

Meyerson LA, Saltonstall K, Windham L, Kiviat E, Findlay S (2000) A comparison of Phragmites australis in freshwater and brackish marsh environments in North America. Wetlands Ecology and Management 8:89-103

Moore GE, Burdick DM, Peter CR, Keirstead DR (2012) Belowground biomass of Phragmites australis in coastal marshes. Northeastern Naturalist 19:611-626

Morzaria-Luna HN, Zedler JB (2007) Does seed availability limit plant establishment during salt marsh restoration? Estuaries and Coasts 30:12-25

Mozdzer TJ, Megonigal JP (2012) Jack-and-master trait responses to elevated $\mathrm{CO}_{2}$ and $\mathrm{N}$ : a comparison of native and introduced Phragmites australis. PLoS One 7:e42794

Mozdzer TJ, Caplan JS, Hager RN, Proffitt CE, Meyerson LA (2016) Contrasting trait responses to latitudinal climate variation in two lineages of an invasive grass. Biological Invasions 18:26649-22660

NOAA (2019) Tides and currents - station ID 8761724. Grand Isle, Louisiana https://tidesandcurrents.noaa.gov/stationhome.html?id= 8761724. Accessed 19 April 2019

Nyman JA, Carloss M, DeLaune RD, Patrick WH Jr (1994) Erosion rather than plant dieback as the mechanism for marsh loss in an estuarine marsh. Earth Surfaces and Landforms 19:69-84

Oksanen J, Blanchet FG, Friendly M, Kindt R, Legendre P, McGlinn D, Minchin PR, O'Hara RB, Simpson GL, Solymos P, Stevens MHH, Szoecs E, Wagner H (2019). vegan: Community Ecology Package. $\mathrm{R}$ package version 2.5-4. https://CRAN.R-project.org/package $=$ vegan Accessed 8 April 2019

Penfound WT, Hathaway ES (1938) Pant communities in the marshlands of southeastern Louisiana. Ecological Monographs 8:1-56 
Price AL, Fany JB, Larkin DJ (2014) Ecology of native vs. introduced Phragmites australis (common reed) in Chicago-area wetlands. Wetlands 34:369-377

Proffitt CE, Travis SE, Edwards KR (2003) Genotype and elevation influence Spartina alterniflora colonization and growth in a created salt marsh. Ecological Applications 13:180-192

Proffitt CE, Chiasson RL, Owens AB, Edwards KR, Travis SE (2005) Spartina alterniflora genotype influences facilitation and suppression of high marsh species colonizing an early successional salt marsh. Journal of Ecology 93:404 416

Reynolds LK, McGlathery KJ, Waycott M (2012) Genetic diversity enhances restoration success by augmenting ecosystem services. PLoS One 7:e38397

Richards CL, Hamrick JL, Donovan LA, Mauricio R (2004) Unexpectedly high clonal diversity of two salt marsh perennials across a severe environmental gradient. Ecology letters 7:1155$1162 \mathrm{t}$

Rooth JE, Stevenson JC (2000) Sediment deposition patterns in Phragmites australis communities: implications for coastal areas threatened by rising sea-level. Wetlands Ecology and Management 8:173-183

Rooth JE, Stevenson JC, Cornwell JC (2003) Increased sediment accretion rates following invasion by Phragmites australis: the role of litter. Estuaries 26:475-483

Saltonstall K (2002) Cryptic invasion by a non-native genotype of the common reed, Phragmites australis, into North America. Proceedings of the National Academy of Sciences USA 99:24452449

Schrift AM, Mendelssohn IA, Materne MD (2008) Salt marsh restoration with sediment-slurry amendments following a drought-induced large-scale disturbance. Wetlands 28:1071-1085

Seliskar DM, Gallagher JL (2000) Exploiting wild population diversity and somaclonal variation in the salt marsh grass Distichlis spicata (Poaceae) for marsh creation and restoration. American Journal of Botany 87:141-146

Seliskar DM, Gallagher JL, Burdick DM, Mutz LA (2002) The regulation of ecosystem functions by ecotypic variation in the dominant plant: a Spartina alterniflora salt-marsh case study. Journal of Ecology 90: $1-11$

Seneca ED, Broome SW, Woodhouse WW Jr, Cammen LM, Lyon III (1976) Establishing Spartina alterniflora marsh in North Carolina. Environmental Conservation 3:185-188

Sheldrick BH, Wang C (1993) Particle size distribution. In: Carter MR (ed) Soil sampling and methods of analysis. Lewis Publishers, Boca Raton, FL, pp 499-511

Silander JA (1984) The genetic basis of the ecological amplitude of Spartina patens. III. Allozyme variation. Botanical Gazette 145: 569-577

Slocum MG, Mendelssohn IA, Kuhn NL (2005) Effects of sediment slurry enrichment on salt marsh rehabilitation: plant and soil responses over seven years. Estuaries 28:519-528

Smith DL, Proffitt CE (1999) The effects of crude oil and remediation burning on three clones of smooth cordgrass (Spartina alterniflora Loisel.). Estuaries 22:616-623

Stagg CL, Mendelssohn IA (2010) Restoring ecological function to a submerged salt marsh. Restoration Ecology 18:10-17

Stagg CL, Mendelssohn IA (2011) Controls on resilience and stability in a sediment-subsidized salt marsh. Ecological Applications 21:17311744

Sweetman AC, Kettenring KM, Mock KE (2013) The pattern and structure of genetic diversity of Schoenoplectus maritimus: implications for wetland revegetation. Aquatic Botany 104:47-54
Taylor KL, Grace JB (1995) The effects of vertebrate herbivory on plant community structure in the coastal marshes of the Pearl River, Louisiana, USA. Wetlands 15:68-73

Thunhorst GA (1993) Wetland planting guide for the northeastern United States: plants for wetland creation, restoration, and enhancement. Environmental Concern, Inc., St. Michaels, Maryland

Tong C, Baustian JJ, Graham SA, Mendelssohn IA (2013) Salt marsh restoration with sediment-slurry application: effect on benthic macroinvertebrates and associated soil-plant variables. Ecological Engineering 51:151-160

Travis SE, Proffitt CE, Lowenfeld RC, Mitchell TW (2002) A comparative assessment of genetic diversity among differently-aged populations of Spartina alterniflora on restored versus natural wetlands. Restoration Ecology 10:37-42

Tumas HR, Shamblin BM, Woodrey M, Nibbelink NP, Chandler R, Nairn C (2018) Landscape genetics of the foundational salt marsh plant species black needlerush (Juncus roemerianus Scheele) across the northeastern Gulf of Mexico. Landscape Ecology 33:1585-1601

Turner RE, Rabalais NN (2003) Linking landscape and water quality in the Mississippi River basin for 200 years. BioScience 53:563-572

Turner RE, Streever B (2002) Dredged material wetlands. In: Turner RE, Streever B (eds) Approaches to coastal wetland restoration: northern Gulf of Mexico. SPB Academic Publishing bv, The Hague, Netherlands, pp 77-96

Utomo HS, Wenefrida I, Materne MD, Harrison SA (2009) Genetic diversity and population genetic structure of saltmarsh Spartina alterniflora from four coastal Louisiana basins. Aquatic Botany 90:30-36

Utomo HS, Wenefrida I, Materne MD, Linscombe JT (2010) Polycross seed of genetically diverse smooth cordgrass (Spartina alterniflora) for erosion control and habitat restoration. Restoration Ecology 18: $170-172$

VanZomeren CM, Berkowitz JF, Piercy CD, White JR (2018) Restoring a degraded marsh using thin layer sediment placement: short term effects on soil physical and biogeochemical properties. Ecological Engineering 120:61-67

Vasquez EA, Glenn EP, Brown JJ, Guntenspergen GR, Nelson SG (2005) Salt tolerance underlies the cryptic invasion of North America salt marshes by an introduced haplotype of the common reed Phragmites australis (Poaceae). Marine Ecology Progress Series 298:1-8

Vellend M (2006) The consequences of genetic diversity in competitive communities. Ecology 87:304-311

Visser JM, Sasser CE, Chabreck RH, Linscombe RG (1998) Marsh vegetation types of the Mississippi River deltaic plain. Estuaries 21: $818-828$

Zedler JB (2000) Progress in restoration ecology. Trends in Ecology and Evolution 15:402-407

Zedler JB (2005) Restoring wetland plant diversity: a comparison of existing and adaptive approaches. Wetland Ecology and Management 13:5-14

Zedler JB, Kercher S (2004) Causes and consequences of invasive plants in wetlands: opportunities, opportunists, and outcomes. Critical Reviews in Plant Science 23:431-452

Zerebecki RA, Crutsinger GM, Hughes AR (2017) Spartina alterniflora genotypic identity affects plant and consumer responses in an experimental marsh community. Journal of Ecology 105:661-673

Publisher's Note Springer Nature remains neutral with regard to jurisdictional claims in published maps and institutional affiliations. 